\title{
Primer registro del copépodo Cymbasoma chelemense (Copepoda: Monstrilloida) en el mar Caribe colombiano
}

\section{First record of the copepod Cymbasoma chelemense (Copepoda: Monstrilloida) in the Colombian Caribbean Sea}

\author{
Edgar Fernando Dorado-Roncancio ${ }^{1}$ and John Dorado-Roncancio ${ }^{2}$ \\ (iD) $0000-0002-0321-5416 \quad$ (iD) $0000-0001-9480-2095$ \\ Instituto de Investigaciones Marinas y Costeras - INVEMAR, Calle $25 N^{\circ} .2-55$, Playa Salguero, Santa Marta, Colombia.edgar.dorado@invemar.org.co \\ 2 Universidad Nacional de Colombia.Departamento de Biología. Sede Bogotá,Colombia.jhdorador@unal.edu.co
}

\section{RESUMEN}

$\mathrm{C}$ omo parte de un monitoreo durante el año 2016 en una bahía estuarina interna en Cartagena, Colombia, se recolectó e identificó un ejemplar hembra adulto de Cymbasoma chelemense. Esta especie fue descrita originalmente para el Golfo de México y comparte las siguientes características morfométricas y morfológicas: Cefalotórax de al menos $68 \%$ del total de la longitud del cuerpo; papila oral localizada en al menos $20 \%$ de la longitud total del cefalotórax; ocelo presente; el complejo genital posee una espina ovígera posicionada en la base y un somite post-genital sencillo, la espina ovígera es al menos $14 \%$ más larga que la longitud total del cuerpo y alrededor de 10 veces la longitud del urosoma. Este es el primer registro de un copépodo del género Cymbasoma en aguas estuarinas colombianas extendiendo el ámbito geográfico de esta especie en el mar Caribe.

PALABRAS CLAVE: Copepoda, Monstrilloida, Cymbasoma, Estuario, Colombia.

\section{ABSTRACT}

$\mathrm{A}$ s part of monitoring in the estuarine inner Bay of Cartagena, Colombia during the year 2016, a female adult specimen of Cymbasoma chelemense was collected and identified. Originally described for the Gulf of Mexico and sharing the following morphological and morphometric characteristics: Cephalothorax of at least $68 \%$ of the total length of the body. Oral papilla located at least $20 \%$ of the total length of the cephalothorax; Ocelli present; genital complex with ovigerous spines located at the base and with one single post genital somites, the ovigerous spines at least $14 \%$ longer than the total length of the body and about 10 times the length of urosome. This is the first record of a copepod of the genus Cymbasoma in Colombia estuarine waters, increasing the range of distribution of this species in the Caribbean Sea.

KEY WORDS: Copépoda, Monstrilloida, Cymbasoma, Estuary, Colombia.

DOI: 10.25268/bimc.invemar.2018.47.2.752 
En la cuenca del Caribe existe una alta riqueza de copépodos, registrando entre 355 (Suárez-Morales et al., 2009) у aproximadamente 700 especies, tendiendo a aumentar de acuerdo con la base de datos que mantiene en actualización el Observatorio Oceanográfico de Banyuls (Razouls et al., 2005-2015). Para el Caribe colombiano son pocos los estudios publicados sobre composición específica del zooplancton, siendo el más completo el realizado por Medellín-Mora y Navas (2010), donde listan 217 especies. Recientemente Fuentes-Reines y Suárez-Morales (2014) adicionaron al listado para el norte del Caribe colombiano 14 especies del orden Harpacticoidea, pero no tenían registro del Orden Monstrilloida Sars, 1903, con lo que el presente trabajo se constituye en el primer reconocimiento de una especie perteneciente a este orden en el Caribe colombiano.

El orden Monstrilloida es uno de los órdenes menos conocidos entre los Copépodos ya que son parásitos durante su fase juvenil y parte de la etapa adulta (Raibaut y Trilles, 1993). Durante los primeros estados de nauplio son endoparásitos principalmente de invertebrados marinos bentónicos como poliquetos errantes de las familias Capitellidae, Serpullidae, Spionidae y Syllidae. En moluscos gasterópodos y bivalvos se introducen en su huésped hasta localizarse en el torrente sanguíneo donde se desarrollan hasta alcanzar la fase preadulta (Caullery y Mesnil, 1914; Davis, 1984; Boxshall y Halsey, 2004), en su fase adulta son organismos planctónicos de vida libre carentes de boca y ano; comúnmente capturados en zonas neríticas y costeras desde los trópicos hasta latitudes altas (Suárez-Morales y Días, 2001; Suárez-Morales e Ivanenko, 2004).

Este orden comprende unas 125 especies que se agrupan en cinco géneros. Las aguas europeas del Atlántico norte son las más diversas (32 especies), seguidas por el mar Caribe y el Golfo de México (24), el Mediterráneo y el mar Negro (20), Indonesia, Malasia y Filipinas (17), Japón (17), Brasil - Argentina (16) y Australia con ocho especies (Suárez-Morales, 2015).

El género Cymbasoma cuenta 66 especies, dentro de las cuales existe un complejo de cinco especies asociadas a Cymbasoma longispinosum, las cuales comparten diferencias sutiles pero consistentes haciendo que la identificación específica sea confusa (Suárez-Morales y Mckinnon, 2016). Este género se encuentra distribuido en diferentes zonas geográficas de Europa y Brasil (C. longispinosum Bourne, 1890), Golfo de México (C. chelemense Suárez-Morales y Escamilla, 1997), Golfo de California (C. californiense Suárez-Morales y Palomares-Garcia, 1999), Japón, Vietnam
The Caribbean basin hosts high copepod richness, registering between 355 (Suárez-Morales et al., 2009) and approximately 700 species, and the number of records is increasing according to the database maintained by the Banyuls Oceanographic Observatory (Razouls et al., 2005-2015). However, few studies have been published on the specific composition of the zooplankton of the Colombian Caribbean, the most complete being that by Medellín-Mora and Navas (2010), who listed 217 species. Recently, Fuentes-Reines and SuárezMorales (2014) added 14 species of the Order Harpacticoidea to the list for the northern Colombian Caribbean, but there was no record for the Order Monstrilloida Sars, 1903. The present work constitutes the first recognition of a species belonging to this order in the Colombian Caribbean.

The order Monstrilloida is one of the least known orders of Copepoda since the members are parasites during the juvenile phase and part of the adult stage (Raibaut and Trilles, 1993), and during the early nauplii stages, they are endoparasites of primarily benthic marine invertebrates such as free-living polychaetes of the families Capitellidae, Serpullidae, Spionidae and Syllidae. In gastropod mollusks and bivalves, monstrillids enter their host and remain in the bloodstream, where they develop until they reach the preadult stage (Caullery and Mesnil, 1914; Davis, 1984; Boxshall and Halsey, 2004). In the adult stage, these copepods are free-living planktonic organisms lacking a mouth and anus, and they are commonly captured in neritic and coastal zones from the tropics to higher latitudes (Suárez-Morales and Días, 2001, Suárez-Morales e Ivanenko, 2004).

This order comprises approximately 125 species that are grouped into five genera; the European waters of the North Atlantic are the most diverse (32 species) followed by the Caribbean Sea and the Gulf of Mexico (24), the Mediterranean and Black Seas (20), Indonesia, Malaysia and the Philippines (17), Japan (17), Brazil and Argentina (16) and finally Australia with eight species (SuárezMorales, 2015).

The genus Cymbasoma comprises 66 species, including a complex of five species associated with "Cymbasoma longispinosum" that shares subtle but consistent differences, making species identification difficult (Suárez-Morales and McKinnon, 2016). This genus is distributed in different geographical areas of Europe and Brazil (C. longispinosum Bourne, 1890), the Gulf of Mexico (Cymbasoma chelemense Suárez-Morales and Escamilla, 1997), the Gulf of California (Cymbasoma californiense Suárez-Morales and Palomares-García, 1999), Japan, 
e India (C. morii Tokioka, 1949), y el mar Rojo y Egipto ( $C$. Janetae Mageed, 2010), evidenciando su amplia distribución (Suárez-Morales, 2011).

La bahía de Cartagena está ubicada al norte del departamento de Bolívar, zona central del Caribe colombiano (Figura 1). Geológicamente corresponde a una bahía, aunque debido al importante aporte de aguas fluviales provenientes del canal del Dique que descargan entre 470.4 y $825.1 \mathrm{~m}^{3} \mathrm{~s}^{-1}$ de agua dulce, actualmente se considera un estuario (CIOH - CARDIQUE, 1997; Garay y Giraldo, 1998; Lonin et al., 2004; Restrepo et al., 2013). El único ejemplar registrado, identificado como Cymbasoma chelemense, fue hallado en una muestra de zooplancton proveniente de la zona denominada ciénaga de las Quintas, bahía interna de Cartagena, durante el periodo de aguas bajas (febrero de 2016) en la estación designada como $P 01$.
Vietnam and India (Cymbasoma morii Tokioka, 1949) and the Red Sea and Egypt (Cymbasoma janetae Mageed, 2010), evidencing its wide distribution (Suárez-Morales, 2011).

The Bay of Cartagena is located north of the department of Bolívar in the central zone of the Colombian Caribbean (Figure 1). Although it is geologically a bay, due to the significant contribution of river water from the Canal del Dique (Dique Channel), which discharges between 470.4 and $825.1 \mathrm{~m}^{3} \mathrm{~s}^{-1}$ of fresh water, it is currently considered an estuary (CIOH - CARDIQUE, 1997; Garay and Giraldo, 1998; Lonin et al., 2004; Restrepo et al., 2013). The only recorded specimen, identified as $C$. chelemense, was found in a zooplankton sample from the area known as Ciénaga de las Quintas in the interior of the Bay of Cartagena during the low-water period (February 2016) at the station designated $P 01$.

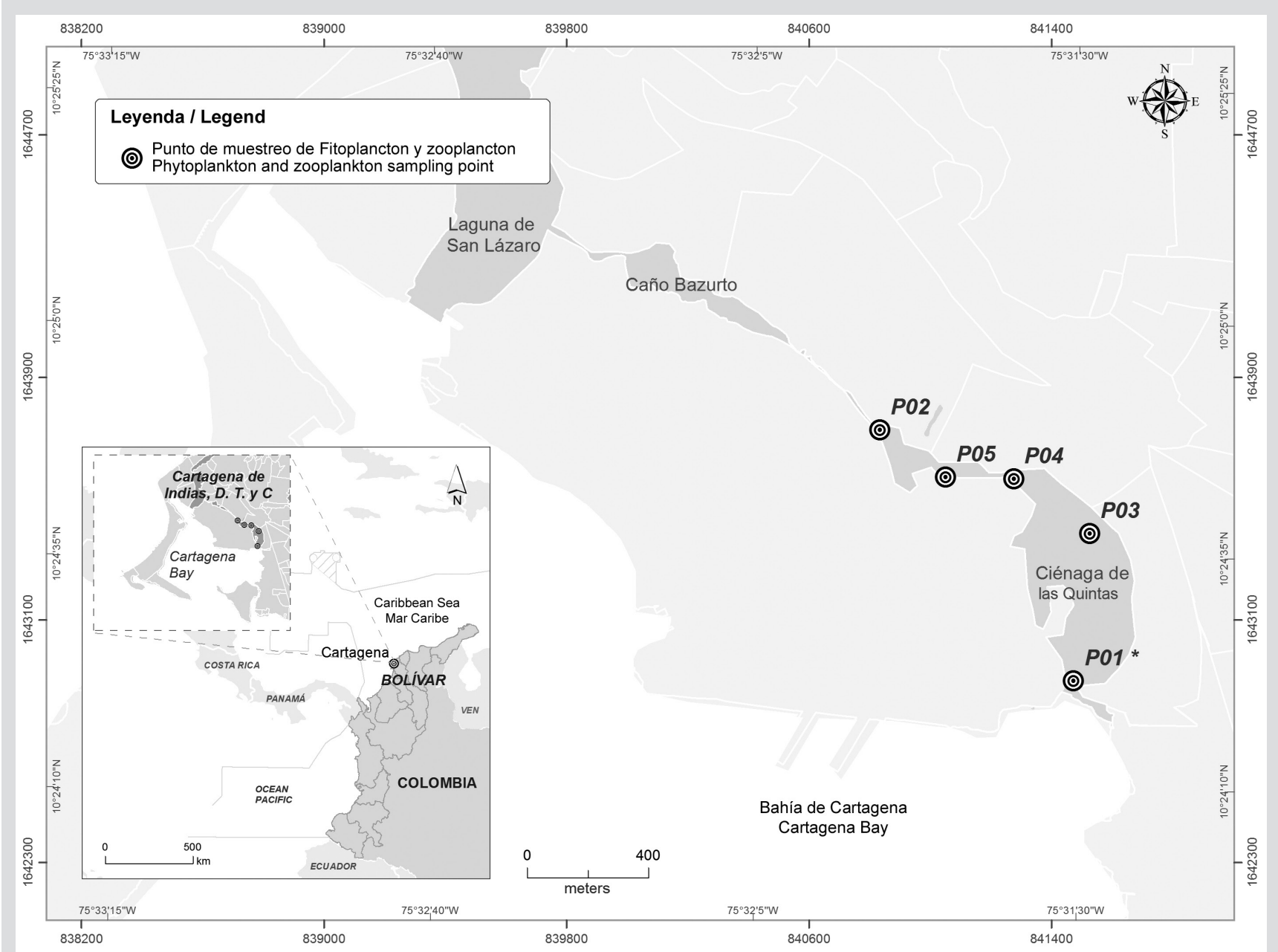

Figura 1. MÁrea de estudio indicando la estación de muestreo con ocurrencia de C. chelemense (P01*) en la ciénaga de las Quintas, bahía de Cartagena, Bolívar. Fuente: LABSIS, INVEMAR.
Figure 1. Map of the study area indicating the sampling station where $C$. chelemense was recorded (P01*) in the Ciénaga de las Quintas, Bay of Cartagena, Bolívar. Source: LABSIS, INVEMAR. 
En cada una de ellas se tomaron $80 \mathrm{~L}$ de agua utilizando un balde plástico de $20 \mathrm{~L}$, los cuales se filtraron usando una red para plancton de $150 \mu \mathrm{m}$ de poro de malla. El material recolectado fue narcotizado con cloruro de magnesio $\left(\mathrm{MgCl}^{2}\right)$ durante 10 minutos, fijado con formol al 4\% neutralizado con bórax y contenido en frascos de 500 $\mathrm{ml}$. Adicionalmente, se tomaron los parámetros in situ de salinidad y temperatura del agua (sonda paramétrica WTW 3210), profundidad (sonda portable Depthmate SM-5), $\mathrm{pH}$ (sonda paramétrica WTW 3110) y oxígeno disuelto (sonda paramétrica WTW Oxi 3205).

La muestra fue luego transportada a los laboratorios del Museo de Historia Natural Marina de Colombia - MAKURIWA donde se procesó la muestra homogenizándola y fraccionándola con separador Folsom (según la densidad de la muestra) en 1/2, 1/4, 1/8 o 1/16 partes siguiendo las recomendaciones de De Oliveira-Díaz et al. (2010). Para corroborar la identificación se tomaron fotografías con un micro estereoscopio Leica serie DFC450. Una vez separado el ejemplar de C. chelemense, se llevó al laboratorio de Microscopía Electrónica de Barrido de la Universidad Nacional de Colombia, donde se tomaron fotografías de estructuras morfológicas útiles para confirmar la identidad taxonómica de la especie, empleando deshidratación por punto crítico mediante un secador Quórum K850 (Lux, 1984; Dykstra y Reuss, 2003).

La muestra y el espécimen se tienen como material de referencia en la colección de plancton del Museo de Historia Natural Marina de Colombia-MAKURIWA del Instituto de Investigaciones Marinas y Costeras - INVEMAR con el número de Catálogo INV CRU 8403.

\section{Phylum Arthropoda}

Subphylum Crustacea Brünnich, 1772

Subclase Copepoda Milne Edwards, 1840

Orden Monstrilloida Sars G.O., 1901

Familia Monstrillidae Dana, 1849

Género Cymbasoma Thompson I.C., 1888

Especie Cymbasoma chelemense Suárez-Morales y

Escamilla, 1997.

Referencias de identificación: Giesbrecht, 1892, p. 37; Björberg, 1981, p. 615; Suárez-Morales y Escamilla, 1997, p. 539; Suárez-Morales, 1999, p. 71; Boxshall y Halsey, 2004, p. 837.

Material examinado: Un ejemplar, hembra, adulto, preservado en seco, deshidratado, sobre un stub
For each sample, $80 \mathrm{~L}$ of water was collected using a $20 \mathrm{~L}$ plastic bucket that was filtered using a $150-\mu \mathrm{m}$ mesh plankton net. The collected material was spiked with magnesium chloride $\left(\mathrm{MgCl}^{2}\right)$ for 10 minutes, fixed with $4 \%$ formalin neutralized with borax and placed in 500-ml flasks. In addition, in situ parameters were measured including water salinity and temperature (WTW 3210 parametric probe), depth (Depthmate SM-5 Portable sounder), $\mathrm{pH}$ (WTW 3110 parametric probe) and dissolved oxygen (WTW Oxi 3205 parametric probe).

The samples were then transported to the laboratories of the Museum of Natural Marine History of Colombia (Museo de Historia Natural Marina de Colombia - MAKURIWA), where they were homogenized and fractionated with a Folsom separator (according to the density of the sample) in $1 / 2,1 / 4,1 / 8$ or $1 / 16$ parts following the recommendations of De Oliveira-Díaz et al. (2010). To confirm the identification, photographs were taken with a Leica DFC-450 series stereo-microscope. Once the $C$. chelemense sample was separated, it was taken to the Scanning Electron Microscopy Laboratory of the National University of Colombia (Universidad Nacional de Colombia) to photograph the diagnostic morphological structures to confirm the taxonomic identity of the species using critical point drying with a Quorum K850 dryer (Lux, 1984; Dykstra and Reuss, 2003).

The sample and the specimen are deposited as reference material in the plankton collection of MAKURIWA of the Institute of Marine and Coastal Research (Instituto de Investigaciones Marinas y Costeras - INVEMAR) with the catalog number INV CRU 8403.

\section{Phylum Arthropoda}

Subphylum Crustacea Brünnich, 1772

Subclass Copepoda Milne Edwards, 1840

Order Monstrilloida Sars G.O., 1901

Family Monstrillidae Dana, 1849

Genus Cymbasoma Thompson I.C., 1888

Species Cymbasoma chelemense Suárez-Morales and Escamilla, 1997.

Identification references: Giesbrecht, 1892, p. 37; Björberg, 1981, p. 615; Suárez-Morales and Escamilla, 1997, p. 539; Suárez-Morales, 1999, p. 71; Boxshall and Halsey, 2004, p. 837

Material examined: One specimen, female, adult, dry preserved, dehydrated, on a stub for electronic 


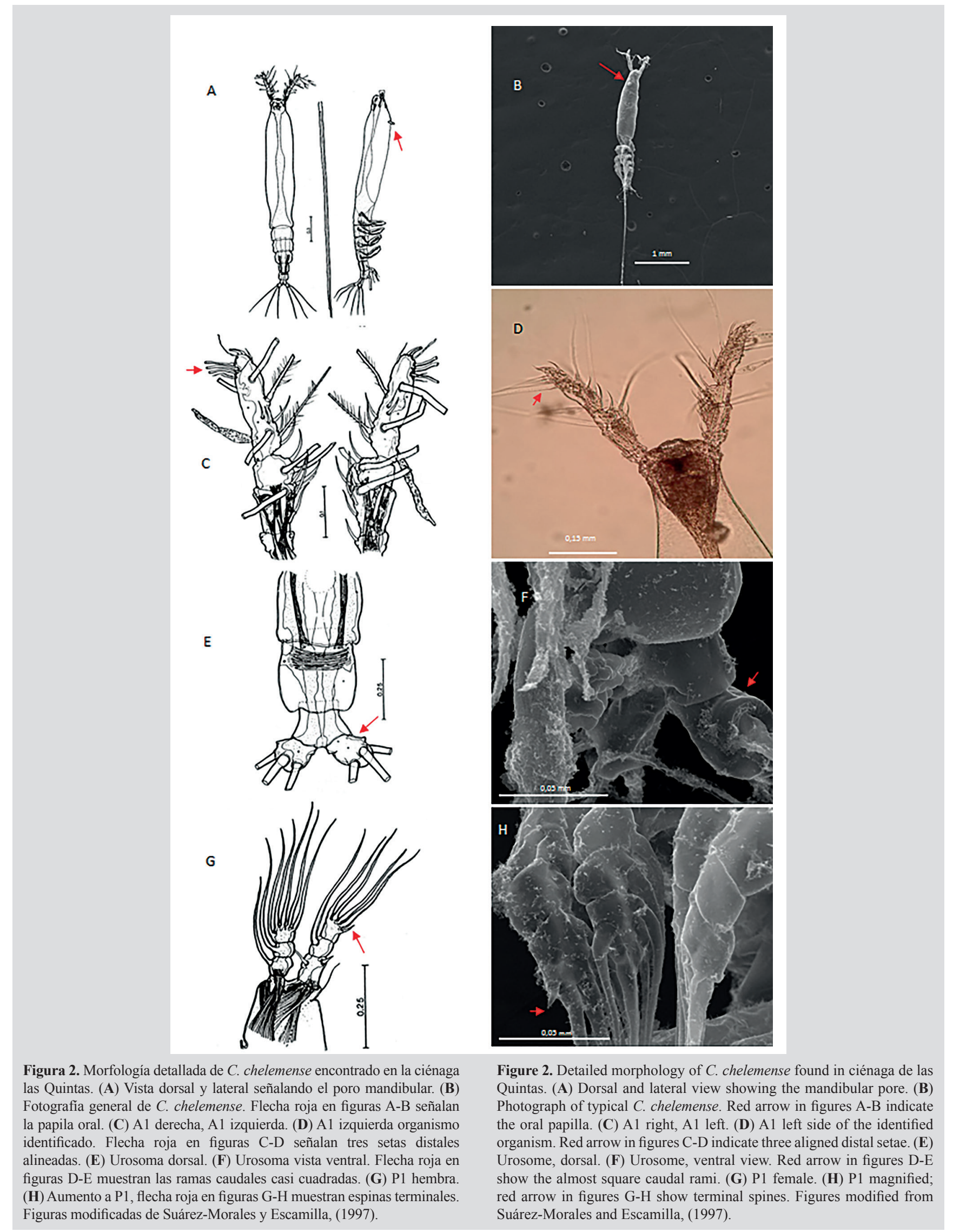


para microscopia electrónica, ingresado como testigo a la colección del Museo de Historia Natural Marina de Colombia con código INV CRU 8403. bahía de Cartagena, Bolívar, Colombia, $2016\left(10^{\circ} 24.364^{\prime} \mathrm{N}\right.$; 75³1.505’ W).

Diagnosis: Cefalotórax casi $68 \%$ del largo total del cuerpo. Papila oral localizada a menos de $20 \%$ del largo de la superficie ventral del cefalotórax (Figura 2 A, B). Cresta cuticular en la frente suave e irregular con forma de remolino. Estrías cuticulares en el urosoma presentes (Figura 2 E, F). Margen posterior del somite genital doble, recto en vista dorsal. Proceso ventral entre las anténulas ausente (Figura $2 \mathrm{C}, \mathrm{E}$ ). Largo relativo entre la anténula/cefalotórax de $21 \%$. Largo relativo del último segmento antenular de $51 \%$. Ocelo presente (Figura 2 D), copas de pigmento medialmente conjugadas, bien desarrolladas, intensamente pigmentadas sólo en la porción central, redondas en vista dorsal. Dos grandes grupos de células sensoriales simples en las porciones laterales de la zona cefálica. Complejo genital con espinas ovígeras, unidas en la base, casi $14 \%$ más largo que la longitud total del cuerpo y unas diez veces más largo que el urosoma.

Distribución: Bahía de Cartagena (este trabajo) y Laguna de Chelem, laguna costera poco profunda ubicada al noreste de la península de Yucatán, México. Área influenciada por aguas cálidas del Caribe y el Golfo de México, la laguna costera se aísla parcialmente de las aguas marinas por bancos de arena que se forman durante la época seca (Suárez-Morales y Escamilla, 1997).

Comentarios: Organismo recolectado en aguas adentro de la ciénaga de las Quintas, bahía interna de Cartagena (Figura 1), en una salinidad de 35.5, temperatura del agua $29^{\circ} \mathrm{C}$, profundidad $<1.90 \mathrm{~m}, \mathrm{pH} 8.09$, Oxígeno disuelto $4.72 \mathrm{mgL}^{-1}$. Suárez-Morales y Escamilla (1997) señalan que la laguna de Chelem (Yucatán - México), donde fue encontrado por primera vez $C$. chelemense, presentó una salinidad de 32.9 , temperatura de $27.5^{\circ} \mathrm{C}$, profundidad entre 0.9 y $1.2 \mathrm{~m}, \mathrm{y} \mathrm{pH}$ de 8.2 .

\section{AGRADECIMIENTOS}

Al INVEMAR, al personal técnico e investigadores del Museo de Historia Natural Marina de Colombia MAKURIWA, al laboratorio de Microscopía Electrónica de Barrido de la Universidad Nacional de Colombia y al Dr. Suárez-Morales por sus comentarios y guía. microscopy, entered as a control in the collection of the Museum of Natural Marine History of Colombia with code INV CRU 8403. Bay of Cartagena, Bolívar, Colombia, 2016 $\left(10^{\circ} 24.364^{\prime} \mathrm{N} ; 75^{\circ} 31.505^{\prime} \mathrm{W}\right)$.

Diagnosis: Cephalothorax almost $68 \%$ of the total length of the body. Oral papillae less than $20 \%$ of the length of the ventral surface of the cephalothorax (Figure $2 \mathrm{~A}, \mathrm{~B})$. Cuticular ridge on the front smooth and irregular with a swirl. Cuticular striae present in the urosome (Figure 2 E, F). Posterior margin of the double genital somite, rectum in dorsal view. Ventral process between antennules absent (Figure 2 C, E). Relative length between the antennule/cephalothorax $21 \%$. Relative length of the last antennal segment $51 \%$. Eye present (Figure 2 D), medially conjugated, well-developed pigment-cups, intensely pigmented only in the central portion, round in dorsal view. Two large groups of simple sensory cells in the lateral portions of the cephalic zone. Genital complex with ovigerous spines, joined at the base, almost $14 \%$ longer than the total length of the body and approximately ten times longer than the urosome.

Distribution: Bay of Cartagena (this work) and Chelem Lagoon (Laguna de Chelem), a shallow coastal lagoon located northeast of the Yucatan Peninsula, Mexico. The area is influenced by warm waters of the Caribbean and the Gulf of Mexico; the coastal lagoon is partially isolated from the marine waters by sand banks formed during the dry season (Suárez-Morales and Escamilla, 1997).

Comments: Organism collected in the inland waters of Ciénaga de las Quintas, the interior of the Bay of Cartagena (Figure 1), at a salinity of 35.5, water temperature of $29^{\circ} \mathrm{C}$, depth $<1.90 \mathrm{~m}, \mathrm{pH} 8.09$, dissolved oxygen $4.72 \mathrm{mg} \mathrm{L}^{-1}$. Suárez-Morales and Escamilla (1997) note that the Chelem Lagoon (Yucatan - Mexico), where $C$. chelemense was first found, presented a salinity of 32.9 , a temperature of $27.5^{\circ} \mathrm{C}$, a depth between 0.9 and $1.2 \mathrm{~m}$, and a $\mathrm{pH}$ of 8.2 .

\section{ACKNOWLEDGEMENTS}

The authors thank INVEMAR, the technical staff and researchers of MAKURIWA, the Scanning Electron Microscopy Laboratory of the National University of Colombia and Dr. Suarez-Morales for his comments and guidance. 


\section{BIBLIOGRAFÍA / LITERATURE CITED}

Björberg, T. 1981. Copépoda. 586-679. En: Boltovskoy, D. (Ed.). Atlas del zooplancton del Atlántico sudoccidental y métodos de trabajo con el zooplancton marino. Publicación Especial del INIDEP. Mar del Plata. 936 p.

Boxshall, G. and S. Halsey. 2004. An introduction to copepod diversity, Vol. 1. The Ray Society. London. 966 p.

Caullery, M. and F. Mesnil. 1914. Sur deux Monstrillides parasites d'Annelides (Polydora giardia Mesn. et Syllis gracilis Gr.). Bull. Sci. Fran. Bel., 48: 15-29.

CIOH - CARDIQUE, 1997. Caracterización y diagnóstico integral de la zona costeras comprendida entre Galerazamba y Bahía de Barbacoas. Tomos I y II. Dirección General Marítima. Convenio de cooperación CIOH-CARDIQUE. Cartagena. 694 p.

Davis, C. 1984. Planktonic Copepoda (including Monstrilloida): 67-91. En: Steidinger, K.A. y L.M. Walter (Eds.). Marine plankton life cycle strategies. CRC Press, Boca Raton. 168 p.

De Oliveira-Díaz, C., A. Valente De Araujo., R. Paranhos and S. Costa-Bonecker. 2010. Vertical Copepod Assemblages (0-2300 m) off Southern Brazil. Zool. Stud., 49(2):230-242.

Dykstra, M. and L. Reuss. 2003. Biological electron microscopy: Theory, techniques and troubleshooting. Springer Science Business Media. 536 p.

Fuentes-Reines, J. and E. Suárez-Morales. 2014. Annotated checklist and new records of Harpacticoida (Copepoda) from a coastal system of northern Colombia, South America. Crustaceana, 87(2):212-255.

Garay, J. y L. Giraldo. 1998. Influencia de los aportes de materia orgánica externa y autóctona en el decrecimiento de los niveles de oxígeno disuelto en la bahía de Cartagena, Colombia. Bol. Cient., CIOH, 18:1-13.

Giesbrecht, W. 1892. Systematik und Faunistik der pelagischen Copepoden des Golfes von Neapel und der angrezenden Meeres-abschnitte. Fauna Flora Golf. Neapel, 19:1-831.

Lonin, S., C. Parra, C. Andrade y Y. F. Thomas. 2004. Patrones de la pluma turbia del Canal del Dique en la Bahía de Cartagena. Bol. Cient., CIOH, 22:77-89. Lux, A. 1984. Manual de microscopia electrónica, ultraestructura y citología vegetal. Volumen I. Universidad Autónoma de Nuevo León. 43p.

Medellín-Mora, J. and G.R. Navas. 2010. Listado taxonómico de copépodos (Arthropoda: Crustacea) del mar Caribe colombiano. Bol. Invest. Mar. Cost., 39(2):265-306.

Raibaut, A. and J. Trilles. 1993. The sexuality of parasitic crustaceans. Advances in Parasitology, 32:367-444.

Razouls, C., F. de Bovée., J. Kouwenberg and N. Desreumaux. 2005 -2015. Diversity and geographic distribution of marine planktonic copepods. http// copepods.obs-banyuls.fr/en. 20/02/2018.

Restrepo, J., D. Franco, J. Escobar, I. Otero y J. Gutierrez. 2013. Bahía de Cartagena (Colombia): distribución de sedimentos superficiales y ambientes sedimentarios. Lat. Am. J. Aquat. Res., 41(1):99-112.

Suárez-Morales, E. 1999. Redescription of the male of Cymbasoma tumorifrons (Isaac, 1975) from the Mediterranean Sea (Copepoda: Monstrilloida). Arthropoda Selecta, 8(1):67-71.

Suárez-Morales, E. 2011. Diversity of the Monstrilloida (Crustacea: Copepoda). Plos One, 6 (8): 1-9.

Suárez-Morales, E. 2015. Clase Maxillopoda: Subclase Copepoda: Orden Monstrilloida. Revista IDE@ - SEA, 96:1-12.

Suárez-Morales, E. and C. O. Días. 2001. A new species of Monstrilla (Copepoda: Monstrilloida) from Brazil with notes on M. brevicornis Isaac. Proc. Biol. Soc. Wash., 114(1):219-228.

Suárez-Morales, E. and J. Escamilla. 1997. An undescribed monstrilloid copepod (Copepoda: Monstrilloida) from the northern Yucatán Peninsula, Mexico. Bull Mar Sci., 61(3):539-547.

Suárez-Morales, E. and V. N. Ivanenko. 2004. Two new species of Monstrillopsis Sars (Crustacea: Copepoda: Monstrilloida) from the White Sea and Norway, with comments on M. dubia Scott. Arctic, 57(1):37-46.

Suárez-Morales, E. and A. D. Mckinnon. 2016. The Australian Monstrilloida (Crustacea: Copepoda) II. Cymbasoma Thompson, 1888. Zootaxa, 4102(1):1129.

Suárez-Morales, E., J.W. Fleeger and P.A. Montagna. 2009. Free-living Copepoda (Crustacea) of the Gulf of Mexico. 841-869. En: Felder, D.L. y D.K. Camp. (Ed.). Gulf of Mexico-origins, waters and biota. Biodiversity. Texas A y M University Press, College Station, Texas. 1393 p. 